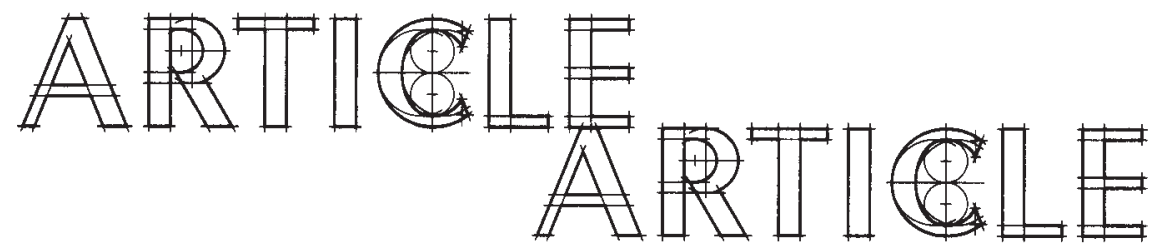

\title{
COETF Annual Awards Program for 2008
}

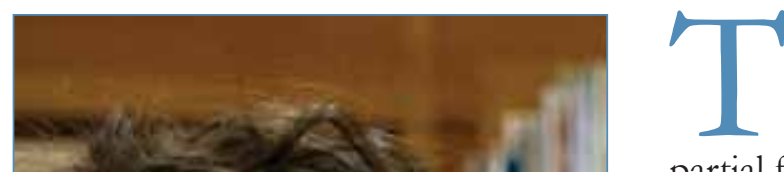

The COETF received a total of 25 applications for awards in 2008. Of those 25 applications, 20 were granted at least partial funding for projects or research. In most cases, applicants are not given full funding as the total amount of funding requested greatly exceeds the money available for granting. Awards funding is based on the Trust Fund's interest earned over the previous year.

All award recipients are required to submit an interim and final report upon completion. In an effort to recognize some of the projects and research being done by COETF award recipients, the Awards Committee intends to publish project reports in the $C$ anadian Journal of 0 ptometry so that our members can learn more about where COETF funding goes as well as highlighting exciting optometric research.

\section{APPLICATIONS SUMMARY}

\begin{tabular}{lcc}
$\begin{array}{l}\text { Total WATERLOO School of } \\
\text { Optometry APPLICATIONS }\end{array}$ & 16 & $\$ 82,730.00$ \\
\hline $\begin{array}{l}\text { Total WATERLOO School of } \\
\text { Optometry AWARDS }\end{array}$ & 13 & $\$ 23,200.00$ \\
$\begin{array}{l}\text { Total MONTRÉAL École } \\
\text { d'Optométrie APPLICATIONS }\end{array}$ & 5 & $\$ 21,695.00$ \\
\hline $\begin{array}{l}\text { Total MONTRÉAL École } \\
\text { d'Optométrie AWARDS }\end{array}$ & 4 & $\$ 7,000.00$ \\
\hline $\begin{array}{l}\text { Total VISION INSTITUTE } \\
\text { Practitioner APPLICATIONS }\end{array}$ & 2 & $\$ 6,800.00$ \\
\hline $\begin{array}{l}\text { Total VISION INSTITUTE } \\
\text { Practitioner AWARDS }\end{array}$ & 1 & $\$ 1,800.00$ \\
\hline $\begin{array}{l}\text { Total INDEPENDENT Practitioner } \\
\text { APPLICATIONS }\end{array}$ & 2 & $\$ 41,200.00$ \\
\hline $\begin{array}{l}\text { Total INDEPENDENT Practitioner } \\
\text { AWARDS }\end{array}$ & 2 & $\$ 5,000.00$ \\
\hline $\begin{array}{l}\text { Total APPLICATIONS for } 2008 \\
\text { Total AWARDS for } 2008\end{array}$ & 25 & $\$ 152,425.00$ \\
\hline $\begin{array}{l}\text { Total APPLICATIONS } \\
\text { (since inception) }\end{array}$ & 20 & $\$ 37,000.00$ \\
\hline Total AWARDS & $\mathbf{\$ 5 , 5 7 5 , 1 4 9 . 7 8}$ \\
\hline
\end{tabular}

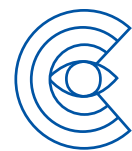

CANADIAN OPTOMETRIC EDUCATION TRUST FUND

Quick Facts:

The Canadian

Optometric Education Trust Fund (COETF)

was created in 1976

by the members of the Canadian Association of Optometrists to assist programs in research, education and human resources development in the vision and eye care field in Canada.

Through its annual program of Awards, the COETF has supported (i) faculty development, (ii) research and/or specialized education programs carried out by graduate students and (iii) investigative projects conducted by undergraduate students enrolled or on staff at Canada's Schools of Optometry. 


\section{ARTICLE ARTICLE}

\section{SCHOOL OF OPTOMETRY, UNIVERSITY OF WATERLOO (UW)}

CANADIAN ASSOCIATION OF OPTOMETRY STUDENTS (Project Supervisor: Dr. B. Robinson): "The Canadian Handbook of Optometry"

CHEN, J., FENG, Y., SIMPSON, T.: "Corneal neural adaptation and symptoms of ocular dryness"

(*** PhD PROGRAM ***/Supervisor Dr. T Simpson)

DALTON, K.: "Diurnal variation in tear film osmoliality" (*** Master's Degree PROGRAM *** / Supervisor Dr. L Jones)

DUENCH, S.: "Conjunctival blood flow and haemoglobin oxygen saturation in conjunctival vessels"

(*** PhD PROGRAM *** / Supervisor Dr. T Simpson)

KEIR, NJ.: "Customised LASIK: A procedure to optomise visual performance following refractive surgery

(Based on current ORE study \#12000)" (*** PhD PROGRAM ***/ Supervisors Drs. L Jones \& T Simpson)

LEAT, S.J., HRYNCHAK, P., IRVING, E..: "Prevalence of binocular vision anomalies in the elderly"

LORENTZ, H.: "Model blink cell apparatus that can be utilized to simulate in vivo lipid deposition"

(*** PhD PROGRAM *** / Supervisor Dr. L Jones)

LORENTZ, N.: "Universal design and the built environment: visual performance factors in universal design"

(*** Master's Degree PROGRAM *** / Supervisor Dr. G Strong)

LUCK, S.: "Cellular changes during lenticular accommodation" (*** Master's Degree PROGRAM *** / Supervisor Dr. V Choh)

LUENSMANN, D.: "To locate proteins of the aqueous humour on the surface and inside intraocular lenses"

(*** PhD PROGRAM *** / Supervisor Dr. L Jones)

MENZIES, K.: "Wettability of silicone hydrogel contact lenses and the impact of care regimens"

(*** Master's Degree PROGRAM *** / Supervisor Dr. L Jones)

PARENT, C. (Optometry Learning Resource Centre):

"Continuance of 'Library Information Resources \& Services for Canadian Optometrists' program"

SRINIVASAN, S.: "Expression of soluble and membrane bound muc16 in dry eye postmenopausal women" (*** PhD PROGRAM ***)

\section{ÉCOLE D'OPTOMÉTRIE, UNIVERSITÉ DE MONTRÉAL}

CARCENAC, G., KERGOAT, H.: "Assessing Vision in Vulnerable Seniors" (*** PhD PROGRAM *** / Supervisor Dr JH. Kergoat)

HAKIM, A.: "Study on Satisfaction and Vision Quality Following Implantation of a

Rezoom Intra-ocular Lens" (*** Master's Degree PROGRAM *** / Supervisor Dr N.M. Quesnel)

HANSSENS, J-M.: "Study on Motion Sickness and Postural Reaction as Part of a Visual-Perceptual Adaptation to Optical Distortion" (*** PhD PROGRAM *** / Supervisor Dr J. Faubert)

LAGACE-NADON, S.: "The Effects of Aging on the Perception of Motion"

(*** Master's Degree PROGRAM *** / Supervisor Dr J. Faubert)

\section{VISION INSTITUTE}

CHIARELLI, C.: "Visagraph III Eye Movement Recording"

\section{INDEPENDENT PRACTITIONER}

BROWNELL, K.: "Relating movement, reading and saccadic disruptions in children"

(*** Post-doctoral program *** / Supervisor Dr. Gord Binsted)

SECEN, J.: "Motion perception deficits in children with amblyopia: A functional MRI"

(*** Master's Degree PROGRAM *** / Supervisor Dr. Deborah Giaschi) 